\title{
Development of Integrated Offline Learning Multimedia to Improve Student Learning Outcomes
}

\author{
M A Kuron,", M L Tompodung ${ }^{\mathrm{b}}$ \\ ${ }^{\mathrm{a}, \mathrm{b}}$ Faculty of Engineering informatics program study, Sariputra Indonesia Tomohon University, INDONESIA \\ * Corresponding author: meidykuron@gmail.com
}

\begin{abstract}
The research about development of integrated offline leaning multimedia aims to improve student learning outcomes and facilitate the learning process effect of use science materials teaching used multimedia software to improve students achievement. The subject of this research is VIIIB class with 22 numbers at Ranoyapo 2 State Junior High School. The research use Research and Delevopment (R \& D) method with design by subject of experiment and seven models of development by Brog and Gall. This model consist of 7 step that are 1) Planning 2) Exploration study 3) Product development 4) Validation, 5) Data collection and analysis, 6) Product revition and 7) Dessimination. This integrated offline learning multimedia has been test by materials and media expert with questioner and has been revision. After that, the integrated offline learning multimedia has been tested by students in class VIIIB to known the student respons and student achievement with straight motion materials at sciences lesson. In the real class, students have given two treatments also called one period and two period. One period, students has teached by conventional models by commonly media used and Second period, students has teached used integrated offline learning multimedia that is research produce. The significant of normality by first period is 0.070 and the second is 0.133 is higher than the 0.05 of degree so that we conclusion that both of period are normal distribution. The analysed of this research used SPSS application be obtained significansi $<0.05$ so H0 is rejected and $\mathrm{H} 1$ is accepted, so the conclution said that there is a significant influence on student learning outcomes between teached by integrated offline leaning multimedia models and teached by conventional models.
\end{abstract}

Keywords: Multimedia software, Junior High School, integrated offline learning, straight motion materials, SPSS.

\section{Introduction}

The quality of learning in schools today is expected to increase along with technological advances that have spread to remote areas therefore teachers are expected to be technology literate so that learning 
objectives can be achieved maximum. Improving educational outcomes at the level of formal education cannot be separated from the resources of teachers and adequate learning facilities one of them facility is learning media. Media is interpreted as a tool that can be used as a distributor of messages to achieve goals. In fact, learning will be more effective if it uses effective media as well. Development of learning media is still considered as an activity that requires a lot of time and cost in its design, although it cannot be denied that currently internet services are very easy to access.

Ranoyapo 2 State Junior high school is located in Amurang South Minahasa region, north Sulawesi province exactly in Poopo village. In the odd semester of the 2017/2018 school year, Ranoyapo 2 state Junior high school has 205 students and 6 study group class. Based on observations that average science subject scores of students at VIIIA class just reach 47,3 and students of IXB class just 42,5 where this value does not reach the minimum standard criteria 70,0 so that the expected students learning outcomes are not achieved optimally. Even though they are technology literate, there are still many students and even teachers in Ranoyapo 2 state junior high schools are difficulty in utilizing online media such as the internet as a learning medium based on information technology. The location of schools that are still in the form of villages and network disruptions is one of the obstacles faced by schools but also the facilities and infrastructure as well as the ability of teachers to use instructional media is still lacking. These problems are obstacles in implementing online information technology based learning.

Multimedia in general can combine three elements, namely sound, images and text. This allows the use of graphics, video, animation, simulation and audio where becomes an interesting and interactive presentation tools in learning (Gunawardhana \& Palaniappan, 2016; Grzeszczyk, 2016). Based on preveous research from (Lindner, 2018) pictures boosted students' confidence in their performance (multimedia heuristic) so that, in the opinion of researchers, integrated offline multimedia design can be the right solution to improve learning outcomes in Ranoyapo 2 state junior high school without having to be connected to the internet so that the learning process continues to run interactively as the main goal in this floating research is to improve student learning outcomes in Ranoyapo 2 state junior high school amid limited infrastructure including internet networks. Based on (Chen \& Sun, 2012; Sousa, 2017) there are three different multimedia materials, static text and image-based multimedia material, video-based multimedia material, and animated interactive multimedia material that affect individual learning performance and emotion. One study from Prosedia Computer Science (Guan, 2018) revealed that the computer multimedia-assisted English teaching has become one of the highlights in English teaching to make the students improve their ability in the process of learning English. So, the benefits of using multimedia in learning sciences material that implements simulations, quizzes, videos combined into one learning media that can be utilized which is expected to improve student learning outcomes.

Previous research revealed that Multimedia is effective for learning, but its adoption mechanism has received less attention. An integrated model is proposed to explain the multimedia adoption behavior for learning (Park, 2019). This research focuses on using three main applications multimedia development programs including of Autoplay, Power Point Microsoft and I-spring Pro. The selection of Power Point Microsoft as a basic program because this program is easily operated by teachers and students, the ISpring Pro is one of the application used to create interactive quizzes and simulations while Autoplay application is used to combine the tree applications. Based on the above background, the researcher deems it necessary to conduct integrated offline multimedia development research to improve students learning outcomes in Ranoyapo 2 state junior high school.

\section{Methods}

This research uses "research and development" methods (R\&D). Research and Development are methods used to produce certain products and make the test of effectiveness products. The steps used follow development studies adapted from (Borg \& Gall. 2003) with 7 steps development there are : 
1) Planning,

2) Exploration study,

3) Development initial forms of products,

4) Data collection and analysis,

5) Validation,

6) Revision based on Validation results,

7) Product Dissemination.

After completing the product stage, it is followed by empirical testing which is used to validity of the product by experiment method with design by subject. Data analysis was performed by paired sample ttest to find out the difference average students learning outcomes in first period and second period with the same subject. The first period is students who are taught with conventional methods with the media commonly used in class and the second period is students who are taught using integrated offline learning multimedia designed in this study.

\section{Results and Discussion}

\subsection{Planning Step}

At this planning stage the researchers conducted a pre-research observation by examining the problems and potential object of research in Ranoyapo 2 state junior high school Poopo Village, so that the multimedia products that were developed is suited to the needs and conditions of the field. The results of the preliminary observations can be seen in table 1 .

Table 1: Preliminary observations on the Research Object

\begin{tabular}{lcc}
\multicolumn{1}{c}{ Study Material } & Yes & No \\
\hline There is a computer laboratory & $\sqrt{ }$ & \\
There is a science laboratory & & $\sqrt{ }$ \\
There is a Projector LCD & & $\sqrt{ }$ \\
Science learning uses a laboratory & $\sqrt{ }$ & \\
Using the 2013-based scientific curriculum & $\sqrt{ }$ & $\sqrt{ }$ \\
Science learning uses printed teaching materials & & $\sqrt{ }$ \\
Science learning uses multimedia & & \\
Teachers and students use several learning resources & $\sqrt{ }$ & $\sqrt{ }$ \\
Learning material based on syllabus and RPP & & \\
There is a school internet network & &
\end{tabular}

The results of the study above indicate that Ranoyapo 2 state junior high school has been equipped with computer laboratory facilities to enable the use of multimedia in the learning process but has not been used due to the limitations of multimedia software-based teaching products. Learning in schools has also used the 2013 curriculum where teachers must apply creative learning methods and media so that the learning process is student-centered.

For this reason, researchers have developed multimedia software-based teaching products with product success criteria of $95 \%$ and $5 \%$ error so that the learning outcomes of VIIIB students grade of Ranoyapo 2 state junior high school can be improved. At this step the instruments were also prepared that would be used, including media expert validation questionnaires on multimedia products, material expert validation questionnaires on straight motion material, learning achievement test instruments used when measuring students learning outcomes. 


\subsection{Exploration Study step}

At this step the study was conducted on two things there are software including teaching material and a study of the conditions at Ranoyapo 2 State Junior High School Poopo Village South Minahasa. Software used in integrated offline learning multimedia has been established are (1) Power Point with Microsoft Office 2017 as a media presentation of teaching materials that are easily designed, attractive appearance and features that are quite complete in making multimedia learning, (2) I-Spring this application serves to make quizzes and practice questions on teaching material that will complement the multimedia created, (3) Autoplay media studio This application is integrated with the two previous applications namely Power Point and I-Spring so that the three applications can run together in one offline learning multimedia package that can be used in learning even without the internet network. Teaching material that is packaged in this learning multimedia that is in the subjects of Natural Sciences (IPA) straight motion material taken from the syllabus used in VIIIB class Ranoyapo 2 State Junior High School odd semester 2019/2020 school year.

The next study is the environmental conditions in Ranoyapo 2 state Junior High School has a distance of $45 \mathrm{~km}$ from the capital city Amurang of South Minahasa Regency. The numbers of students odd semester 2019/2020 school year are 153 students consists of 6 groups study there are VIIA class included 26 students, VIIB class included 23 students, VIIIA class included 23 students, VIIIB class included 22 students, IXA class included 30 students and IXB class included 29 students. There are 16 teachers with 1 headmaster. The research object is VIIIB class with 22 students where 12 male students and 10 fimale students. Facilities and infrastructure such as buildings, class, simple laboratories, tables, chairs, blackboards, sports fields are good although learning facilities based on information technology are still lacking such as the unavailability of LCD projectors, lack of computers, no multimedia learning, and no network Internet.

\subsection{Development initial forms of products}

The product development stage begins with the design of the initial form of the product using multimedia software. The steps as follows:

1) Installing autoplay media studio, i-spring and power point microsoft office

2) Make a presentation of straight motion material according to syllabus and RPP that have been prepared in advance using the power point application

3) Create quizzes and practice questions using the i-spring application

4) Evaluation of prototype design multimedia products.

The results of the initial design product using multimedia software can be seen in the figure 1 

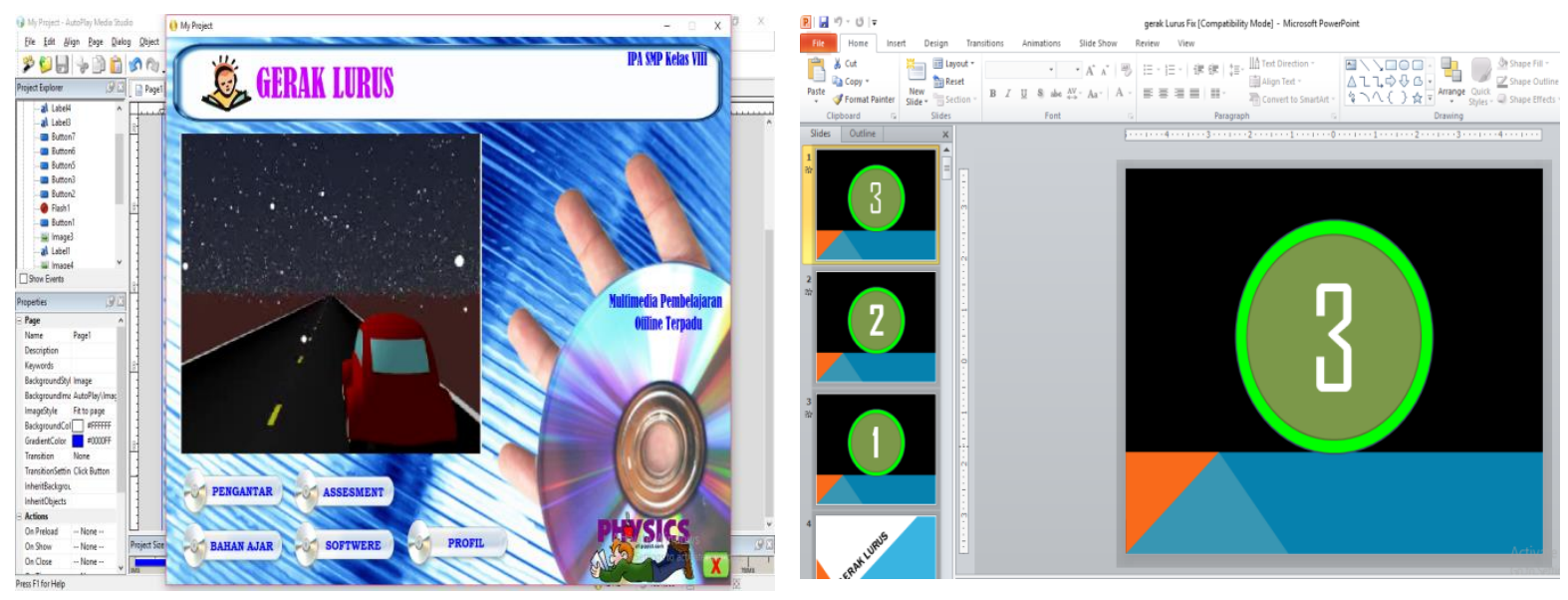

Figure 1: Initial design product using multimedia software

\subsection{Expert Validation}

\subsubsection{Media expert validation}

Media expert validation aims to evaluate the overall application used from image quality, display clarity, running speed, ease of access, accuracy of video and flash, link navigation and so on using the linkert scale questionnaire that has been prepared (Kay \& Knaack, 2017). This validation was carried out by lecturer at Faculty of Engineering at Manado State University. The results of media expert validation before the field test can be seen in table 2 .

Table 2: Media expert validation of multimedia learning offline

\begin{tabular}{|c|c|c|c|c|c|c|}
\hline \multirow{3}{*}{ No } & \multirow{3}{*}{ Assessment Indicators } & \multicolumn{5}{|c|}{ Alternative Options } \\
\hline & & $\mathrm{SB}$ & $\mathrm{B}$ & $\mathrm{CB}$ & $\mathrm{KB}$ & TB \\
\hline & & 5 & 4 & 3 & 2 & 1 \\
\hline \multicolumn{7}{|c|}{ Display Eligibility } \\
\hline 1 & Product initial appearance & $\sqrt{ }$ & & & & \\
\hline 2 & Text is clear and legible & $\sqrt{ }$ & & & & \\
\hline 3 & Video/flash/animation are not disturbed & & $\sqrt{ }$ & & & \\
\hline 4 & Audio sounds is clear & & $\sqrt{ }$ & & & \\
\hline 5 & Integration of composition and color & $\sqrt{ }$ & & & & \\
\hline 6 & Function as a media learning & & $\sqrt{ }$ & & & \\
\hline 7 & The link / navigation tool works good & & $\sqrt{ }$ & & & \\
\hline 8 & Accessibility & & & $\sqrt{ }$ & & \\
\hline 9 & Image display quality & & $\sqrt{ }$ & & & \\
\hline 10 & Endurance of independent and group activities & & $\sqrt{ }$ & & & \\
\hline \multicolumn{7}{|c|}{ Presentation Eligibility } \\
\hline 11 & Systematic presentation & & $\sqrt{ }$ & & & \\
\hline 12 & Material is easy to understand & & & $\sqrt{ }$ & & \\
\hline 13 & Presentation is easy to follow & & $\sqrt{ }$ & & & \\
\hline 14 & Video makes it easy to understand the material & & $\sqrt{ }$ & & & \\
\hline
\end{tabular}




\begin{tabular}{llllll}
15 & Easy to understand concept & & $\sqrt{ }$ & \\
16 & Ease of understanding examples / practice & & & \\
& & & & \\
& questions & & & & \\
\hline Supporting Eligibility & $\sqrt{ }$ & & & \\
\hline 17 & A support program is available to install & $\sqrt{ }$ & & & \\
18 & Ease of installing programs & & $\sqrt{ }$ & & \\
19 & Can run on other computers & & $\sqrt{ }$ & & \\
20 & Program response speed & 25 & 44 & 12 & 0 \\
\hline & Total Score & & & & \\
\hline
\end{tabular}

Very good answer (SB) 5 score as much 5 indicator good answer (B) 4 score as much 11 indicator good enough answer (CB) 3 score as much 4 indicator not good answer $(\mathrm{KB}) 2$ score as much 0 indicator bad answer (TB) 1 score as much 0 indicator

$$
\begin{aligned}
& 5 \times 5=25 \\
& 4 \times 11=44 \\
& 3 \times 4=12 \\
& 2 \times 0=0 \\
& 1 \times 0=0+ \\
& \hline \text { total } 81
\end{aligned}
$$

Based on the data, the percentage of the count is calculated by comparing the number of scores achieved with the maximum number multiplied by $100 \%$ with the interpretation of scores:

$$
\frac{\text { Total Score Achieved }}{\text { Maximum Score }} \times 100 \%=\frac{81}{100} \times 100 \%=81 \%
$$

The following categories can be made:

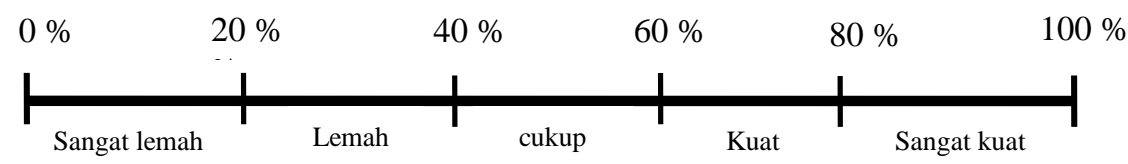

Figure 2: Categories of multimedia learning offline by media expert

The results show a percentage of $81 \%$ and included in the category of very strong (Arikunto, 2010). Suggestions from media experts were revised before field testing.

\subsubsection{Materials expert validation}

Materials expert validation aims to validate the learning materials contained in this integrated offline

\begin{tabular}{|c|c|c|c|c|c|c|}
\hline \multirow{3}{*}{ No } & \multirow{3}{*}{ Indicators } & \multicolumn{5}{|c|}{ Alternative Options } \\
\hline & & SB & $\mathrm{B}$ & $\mathrm{CB}$ & $\mathrm{KB}$ & TB \\
\hline & & 5 & 4 & 3 & 2 & 1 \\
\hline
\end{tabular}
learning multimedia (Andresen \& Brink, 2013; Almara'beh et al, 2015). The material used is straight motion in accordance with the syllabus and RPP at VIIIB class Ranoyapo 2 State Junior High School. Media experts in this study were drawn by Natural Sciences lecturer from Sariputra Indonesia University Tomohon.

Table 3: Material expert validation of multimedia learning offline 


\begin{tabular}{lll}
\hline 2 & science methods \\
3 & The teaching material has the right concept \\
Teaching materials contain new things & The material in teaching material is developed based on \\
4 &
\end{tabular}

Table 3 explains the material expert's assessment of the material substance contained in the development of offline multimedia. the results of the expert judgment can be interpreted as follows:

Very good answer (SB) 5 score as much 6 indicator good answer (B) 4 score as much 5 indicator good enough answer (CB) 3score as much 2 indicator not good answer (KB) 2 score as much 2 indicator bad answer (TB) 1 score as much 0 indicator

$$
\begin{aligned}
& 5 \times 6=30 \\
& 4 \times 5=20 \\
& 3 \times 2=6 \\
& 2 \times 2=4 \\
& 1 \times 0=0+ \\
& \hline \text { total } 60
\end{aligned}
$$

Based on the data, the percentage of the count is calculated by comparing the number of scores achieved with the maximum number multiplied by $100 \%$ with the interpretation of scores:

$$
\frac{\text { Total Score Achieved }}{\text { Maximum Score }} \times 100 \%=\frac{60}{75} \times 100 \%=80 \% \text {. }
$$

The following categories can be made:

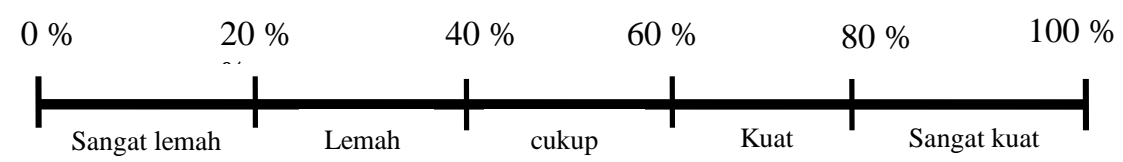

Figure 3: Categories of multimedia learning offline by materials expert 
The results show a percentage of $80 \%$ and included in the category of very strong (Arikunto, 2010). Suggestions from materials experts were revised before field testing.

\subsection{Data collection and analysis}

This step, a field test using integrated offline multimedia was carried out for the VIIIB grade students of Ranoyapo 2 State Junior High School, totaling 22 students. At this stage an empirical study was carried out using a quasi-experimental method design by subject. Data collection was obtained from students achievement test in first period and second period where the first period is student who are taught with conventional methods with the media commonly used in class and the second period is student who are taught using integrated offline learning multimedia designed in this study.

\subsubsection{Student Learning Outcomes Description}

Student learning outcomes data consists of two periods, namely 1 period where students taught with conventional models with the media commonly used at school and 2 period where students who are taught using integrated offline learning multimedia. The first period is done before washing out and the second period after washing out. Student learning outcomes data from 1 period and 2 period can be seen in the following table 4.

Tabel 4: The Statistics of Student learning outcomes

\begin{tabular}{ccc}
\hline & $\begin{array}{c}\text { 1 Period } \\
\text { (Convensional) }\end{array}$ & $\begin{array}{c}\text { 2 Period } \\
\text { (Multimedia offline) }\end{array}$ \\
\hline $\mathrm{N}$ & 22 & 22 \\
Total & 1010 & 1570 \\
Min Score & 20 & 40 \\
Max Score & 74 & 90 \\
STDV & 18.88 & 13.08 \\
Mean & 45.90 & 71.36 \\
Median & 45 & 73 \\
Modus & 20 & 80 \\
\hline
\end{tabular}

From the table 4 about 1 period the total score of student learning outcomes is 1010 with a minimum score of 20, a maximum score of 74 and an average learning result of 45.90, and the data with the highest frequency are 20 out of 22 students. The histogram of students learning outcomes for 1 period can be seen in figure 4 


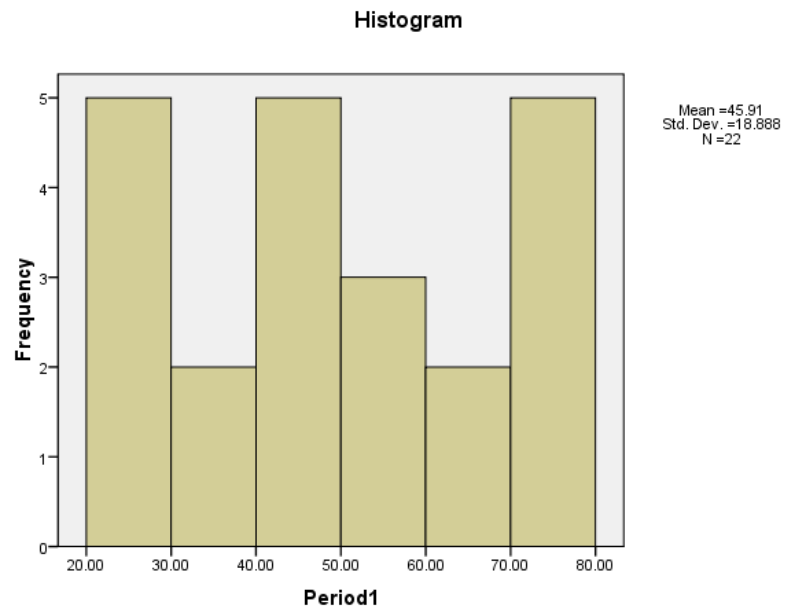

Figure 4: Histogram of students learning outcomes for 1 period

In 2 period a minimum score of 40, a maximum score of 90, an average of 71.36 learning outcomes and the data with the highest frequency were 80 out of 22 students. The histogram of student learning outcomes in 2 period can be seen in figure 5

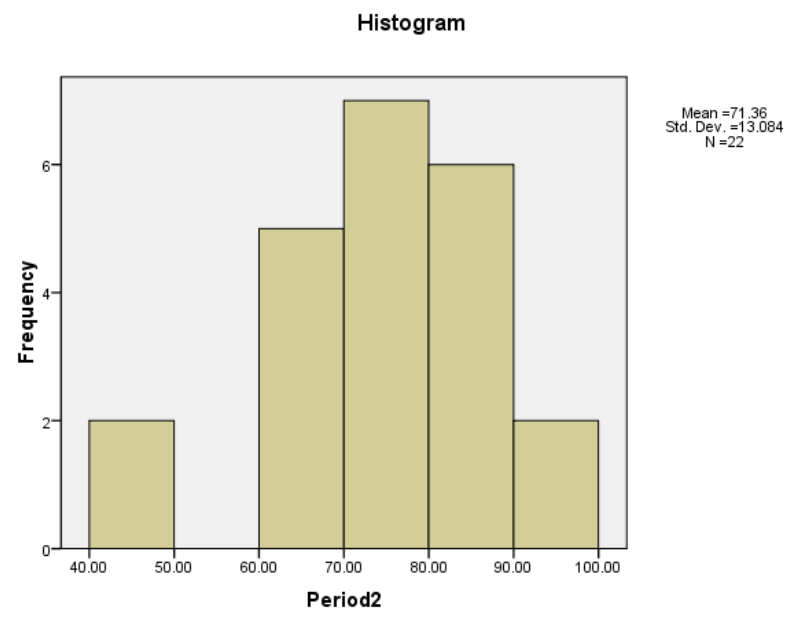

Figure 5: Histogram of students learning outcomes for 2 period

\subsubsection{Normality Analysis}

The normality test of students learning outcomes is carried out over 1 period and 2 period. The normality test uses the Shapiro-Wilk and Kolmogorov-Smirnov by SPSS tests with the following criteria: If (sig.) significant $>0,05$ normally distributed data If ( $\mathrm{sig}$ ) significant $<0,05$ unnormally distributed data 
(Ghasemi \& Zahediasl, 2012; Razali et al, 2012)

$\alpha=0,05$ and $n=22$. The results of the normality test can be seen in table 5 below

Table 5: Tests of Normality

\begin{tabular}{lcccccc}
\hline \multicolumn{4}{c}{ Kolmogorov-Smirnov $^{\text {a }}$} & \multicolumn{3}{c}{ Shapiro-Wilk } \\
\hline Statistic & df & Sig. & Statistic & df & Sig. \\
\hline Period1 & .126 & 22 & $.200^{*}$ & .918 & 22 & .070 \\
Period2 & .140 & 22 & $.200^{*}$ & .932 & 22 & .133 \\
a. Lilliefors Significance Correction & & & & \\
*. This is a lower bound of the true significance. \\
\hline
\end{tabular}

Significant value in 1 period was obtained by 0.200 and 2 period was obtained by 0.070 greater than the standar level of 0.05 so it can be concluded that both data in 1 period and 2 period were normally distributed.

\subsubsection{Hypothesis test}

Hypothesis test (Bhalerao \& Parab, 2010) uses paired-samples t-test which is an analysis involving two measurements on the same subject to a certain influence or treatment to test the difference in average learning outcomes as in the case of this study. The results hypothesis test by SPSS can be seen in table 6 .

Table 6: Paired Samples Statistics

\begin{tabular}{cccccc}
\hline & Mean & N & Std. Deviation & Std. Error Mean \\
\hline \multirow{2}{*}{ Pair 1 } & Period1 & 45.9091 & 22 & 18.88791 & 4.02692 \\
\cline { 2 - 6 } & Period2 & 71.3636 & 22 & 13.08414 & 2.78955 \\
\hline
\end{tabular}

Output of the first part (paired samples statistics): This section presents a description of the data from the pair of variables analyzed including the number of samples 22 , the average 1 period is 45.90 with a standard deviation of 18.8 and the average 2 period is 71.36 with the standard deviation 13.08 .

Table 7. Paired Samples Correlations

\begin{tabular}{ccccc}
\hline & & N & Correlation & Sig. \\
\hline Pair 1 & Period1 \& Period2 & 22 & .720 & .000 \\
\hline
\end{tabular}

Output of the second part (paired samples correlations): In this section the correlation results between 
the two variables produce the number 0.720 and the probability value (sig.) 0.000 .

If $\operatorname{sig}>0,05$ no significant relations

If sig $<0,05$ significant relations

The result $0.000<0.05$ states that the correlation between students learning outcomes taught with conventional models with the usual media used (1 period) and students learning outcomes taught by using integrated offline learning multimedia ( 2 period) are significantly related to the correlation value approaching 0.720 .

Table 8. Paired Samples Test

\begin{tabular}{|c|c|c|c|c|c|c|c|c|}
\hline & \multicolumn{5}{|c|}{ Paired Differences } & \multirow[b]{3}{*}{$\mathrm{t}$} & \multirow{3}{*}{\multicolumn{2}{|c|}{$\begin{array}{cc} & \text { Sig. } \\
\text { df } & \text { (2-tailed) }\end{array}$}} \\
\hline & \multirow[b]{2}{*}{ Mean } & \multirow{2}{*}{$\begin{array}{c}\text { Std. } \\
\text { Deviation }\end{array}$} & \multirow{2}{*}{$\begin{array}{c}\text { Std. Error } \\
\text { Mean }\end{array}$} & \multicolumn{2}{|c|}{$\begin{array}{l}\text { 95\% Confidence Interval } \\
\text { of the Difference } \\
\end{array}$} & & & \\
\hline & & & & Lower & Upper & & & \\
\hline Pair 1 Period 1 - Period 2 & $-2.54545 \mathrm{E} 1$ & 13.11026 & 2.79512 & -31.26731 & -19.64178 & -9.107 & 21 & .000 \\
\hline
\end{tabular}

Output of the third section (Paired samples t-test): In this section a difference in mean of -2.54 indicates the difference between the average learning outcomes of 1 period with the average learning outcomes of 2 period or $4,590-7,136=-2.54$ the difference between $-31,26731$ to $-9,107$ (95\% confidence interval of the difference). Besides that there is a standard deviation difference value (STD) 13.11 and the results of the t-test -9.107 with free degrees (df) $22-1=21$ confidence level of $95 \%$ and significant 0.000 while the statistical table (t-table) 2.074. In this study the following statistical hypotheses are presented:

Ho $=\mu_{1} \leq \mu_{2}: \quad$ "There is no average difference between students learning outcomes in 1 period and 2 period".

This means that there is no significant influence of the use integrated offline learning multimedia on students learning outcomes.

$\mathbf{H}_{1}=\boldsymbol{\mu}_{1}>\boldsymbol{\mu}_{2}: \quad$ "There is average difference between students learning outcomes in 1 period and 2 period".

This means that there is significant influence of the use integrated offline learning multimedia on students learning outcomes.

Based on significance (Cho \& Abe, 2011; Mourougan \& Sethuraman, 2017) :

$$
\begin{aligned}
& \text { If } \operatorname{sig}(2-\text { tailed })>t_{\alpha}(\alpha=0.05) \text { accepted } \mathrm{H}_{0} \text { rejected } \mathrm{H}_{1} \\
& \text { If } \operatorname{sig}(2-\text { tailed })<t_{\alpha}(\alpha=0.05) \text { rejected } \mathrm{H}_{0} \text { accepted } \mathrm{H}_{1}
\end{aligned}
$$

Furthermore, based on Paired samples t-test table sig values. (2-tailed) of 0,000<0.05 then reject $\mathrm{H}_{0}$ and accept $\mathrm{H}_{1}$ so that it can be concluded related to the significance of learning outcomes in 1 period and learning outcomes in 2 period which means there is an integrated use of offline learning multimedia on student learning outcomes for science subjects straight motion material VIIIB class Ranoyapo 2 state Junior High School. 
Drawing conclusions by comparing the calculated tvalue and ttable value as follows:

Based on the calculated value :

$$
\begin{aligned}
& \text { If } t_{\text {value }} \leq t_{\text {table }} \text { accepted } \mathrm{H}_{0} \text { rejected } \mathrm{H}_{1} \\
& \text { If } t_{\text {value }}>t_{\text {table }} \text { rejected } \mathrm{H}_{0} \text { accepted } \mathrm{H}_{1}
\end{aligned}
$$

It is known that the tvalue is negative which is equal to $-9,107$ due to the average value of learning outcomes in 1 period which is lower than the average value of learning outcomes in 2 period. For this reason, in this case the value of $t$ arithmetic negative can be positive. tvalue> ttable or 9,107> 2,074 then reject $\mathrm{H}_{0}$ and accept $\mathrm{H}_{1}$ or it can be concluded that there is an average difference between students learning outcomes in 1 period and student learning outcomes in 2 period. That means that there is an influence of using integrated offline learning multimedia on student learning outcomes for subjects Science of straight-motion material VIIIB class Ranoyapo 2 state Junior High School.

\subsection{Product revision based on validation results}

After conducting field tests on 22 students and getting conclusions from empirical tests on student learning outcomes, the product developed was revised again based on suggestions and input at the field test steps both from subject teachers and students. The results of this product revision include:

1) Reduction of animation on products that make the long process

2) Making the "on" and "off" on the sound and music to be clear

3) Straight-motion teaching material plus more practice questions.

The results of the final product revision and the results of empirical testing make the development of integrated offline learning multimedia products very good for use in classroom learning without having to use the internet. The final of multimedia figure after revised results. For that reason, as a conclusion of this research, the development of integrated offline learning multimedia with natural sciences on straight motion materials can improve student learning outcomes. As the preveous research from (Molina, 2018) the design of multimedia materials can influence in the learning efficiency.
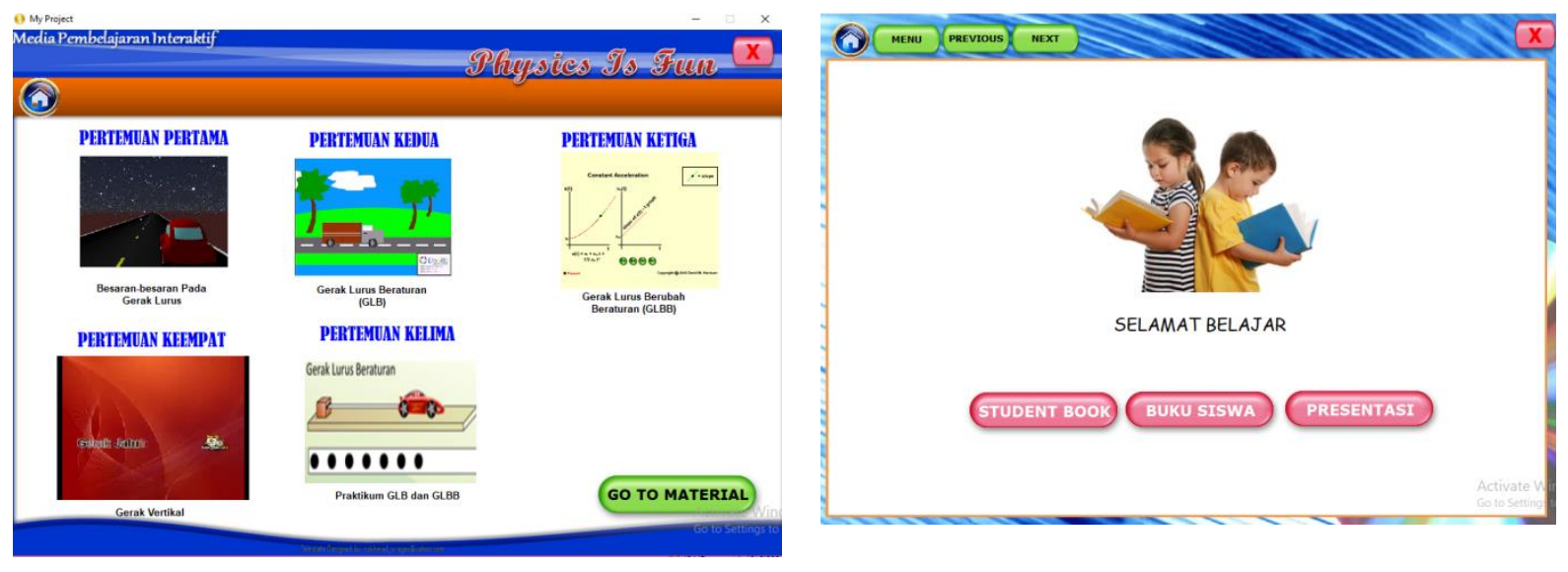

Figure 6: Final of multimedia offline learning

\section{Conclussion}


The results of the research development of integrated offline learning multimedia were disseminated in international journals of Scopus and were disseminated at the 2019 IORA International Conference on Operations Research. The results of this multimedia product are packaged in an interactive CD to be given at Ranoyapo 2 State Junior High School to be used in learning with hope that it will benefit for everyone. The conclution said that there is a significant influence on student learning outcomes between teached by integrated offline leaning multimedia models and teached by conventional models.

\section{Acknowledgments}

A big thank you to Ministry of Research, Technology and High Education, Directorate General of Research and Development, Research and Community Development of Sariputra Indonesia Tomohon University, LL-Dikti regional IX. Thank you to all family, friends and all who help and supported.

\section{References}

Almara'beh, H., Amer, E. F., Sulieman, A. (2015). The effectiveness of multimedia learning tools in education. International Journal of Advanced Research in Computer Science and Software Engineering. 5(12), 761-764.

Andresen, B. B., \& Brink, K. 2013. Multimedia in Education Curriculum. Moscow : UNESCO Institute for Information Technologies in Education.

Arikunto, S. (2010). Prosedur Penelitian: Suatu Pendekatan Praktik, Ed. rev. 2010 , cet.14. Jakarta: Rineka Cipta.

Bhalerao, S., \& Parab, S. (2010). Choosing statistical test. International Journal of Ayurveda Research. 1(3), 187191. doi:10.4103/0974-7788.72494

Borg \& Gall. (2003). Education Research. New York : Allyn and Bacon.

Chen, C., \& Sun, Y. (2012). Assessing the effects of different multimedia materials on emotions and learning performance for visual and verbal style learners. Computers \& Education, 1273-1285.

Cho, H., \& Abe, S. (2013). Is Two-tailed Testing for Directional Research Hypotheses Tests Legitimate?. Journal of Business Research. 66(9), 1261-1266. DOI: 10.1016/j.jbusres.2012.02.023.

Ghasemi, A., \& Zahediasl, S. (2012). Normality Tests for Statistical Analysis: A Guide for Non-Statisticians. International Journal of Endocrinology \& Metabolism. 10(2), 486-489. DOI: 10.5812/ijem.3505.

Grzeszczyk, K. B. (2016). Using multimedia in the English language classroom. World Scientific News. 43(3), 104-157.

Guan, N. (2018). On the Advantages of Computer Multimedia-aided English Teaching. Procedia Computer Science. 131, 727-732.

Gunawardhana, L. K. P. D., \& Palaniappan, S. (2016). Using multimedia as an education tool. In 9th Annual International Conference on Computer Games, Multimedia and Allied Technology (CGAT 2016). doi: 
10.5176/2251-1679_CGAT16.15.

Horowitz, G.T., Maldacena, J. (2004). The black hole final state. J. High Energy Phys. JHEP02(2004)008.

Kay, R. H., \& Knaack, L. (2017). Evaluating the learning in learning objects. Open Learning. 22(1), 5-28.

Lindner, M. A. (2018). An integrative study on learning and testing with multimedia:Effects on students' performance and metacognition. Learning and Instruction online 7 March 2018, 101100.

Molina. A. I. (2018). Evaluating multimedia learning materials in primary education using eye tracking. Volume 59, Pages 45-60.

Mourougan, S., \& Sethuraman, K. (2017). Hypothesis Development and Testing. IOSR Journal of Business and Management (IOSR-JBM). 9(5), 34-40. DOI: 10.9790/487X-1905013440.

Park, C. W. (2019). Adoption of multimedia technology for learning and gender difference. Computers in Human Behavior. Volume 92, 288-296.

Razali, N. M., Shamsudin, N. R., Maarof, N. N. N. A., Hadi, A. A., \& Ismail, A. (2012). A comparison of normality tests using SPSS, SAS and MINITAB: An application to Health Related Quality of Life data. In 2012 International Conference on Statistics in Science, Business and Engineering (ICSSBE). doi:10.1109/icssbe.2012.6396570.

Setyosari, P. (2010). Metode Penelitian Pendidikan dan Pengembangan. Jakarta : Prenada Media Group.

Sousa, L. (2017). The effect of multimedia use on the teaching and learning of Social Sciences at tertiary level: A case study. Yesterday \& today. No. 17. 